\title{
U.PORTO
}

FMUP FACULDADE DE MEDICINA

UNIVERSIDADE DO PORTO

\section{The influence of professionals' empathy on parents' anxiety in cases of juvenile criminology}

\author{
Juliana Canedo Rocha
}

Dissertação submetida para obtenção do grau de Mestre em Comunicação Clínica Faculdade de Medicina da Universidade do Porto

Orientadora: Professora Doutora Irene Maria Palmares Dias Carvalho 


\section{Agradecimentos}

À Professora Doutora Irene Carvalho, pelo acompanhamento e orientação prestada durante o processo de realização do projeto, pela motivação e dedicação nos momentos de maior dificuldade.

Ao Professor Doutor Rui Guimarães, pela disponibilidade e prestabilidade, possibilitando a realização deste processo.

A toda a equipa do serviço do PIAC, nomeadamente à Dr. ${ }^{a}$ Ana, Dr. ${ }^{a}$ Vera, Dr. ${ }^{a}$ Iolanda, aos administradores do Psicossocial, António, Rosa e Patrícia pela forma como me receberam e acolheram, fazendo-me sentir integrada nesta equipa.

Aos meus pais, pela oportunidade de estudar e de concretizar todos os meus objetivos de vida, por sempre acreditarem que os ia alcançar. Obrigada por todos valores, por todos conselhos, por toda a força e determinação transmitida, por tudo... porque sem vocês a minha vitória não teria o mesmo sabor, nem o mesmo significado. Obrigada pai, obrigada mãe, por serem os maiores exemplos da minha vida, por acreditarem sempre na minha capacidade, por me incentivarem a chegar ao último "round" sem que fosse necessário atirarem a toalha ao chão ou que eu ficasse K.O. E aos meus irmãos, os meus mais que tudo, Lara e Ivan.

Ao Ricardo, por nunca me deixar desamparada, por me ter dado a mão nos momentos em que eu pensei que o mundo ia acabar. Obrigada pela proteção, pela paciência, pelo carinho, por todo o amor e por realçares o melhor de mim.

Ao Sr. Pinto Lopes, por partilhar comigo a sua sabedoria enquanto mentor. Obrigada por me ter ensinado a saborear a vitória e a digerir a derrota enquanto atleta e mulher. Obrigada pelo suporte e por ser um pilar importante na minha vida.

Aos meus amigos que me acompanharam neste percurso e que me inspiraram a ser mais e melhor. 
"O desafio é enorme, mas a vontade de vencer é ainda maior!" 


\section{INDEX}

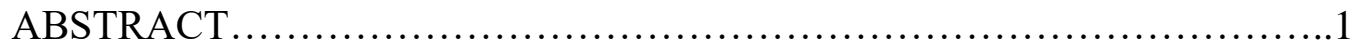

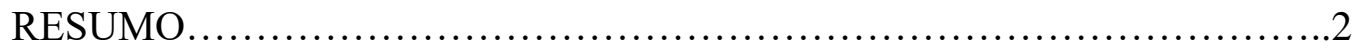

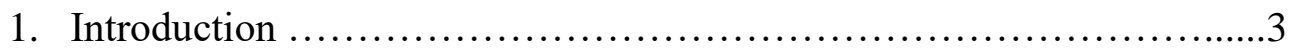

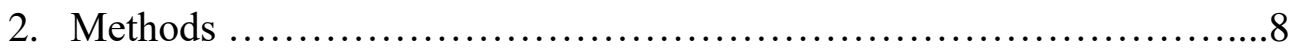

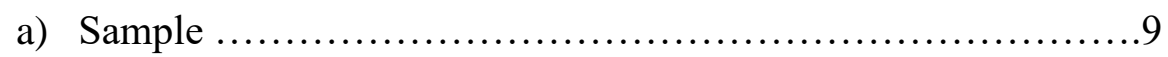

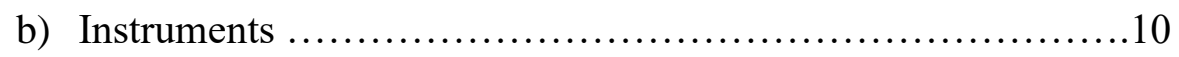

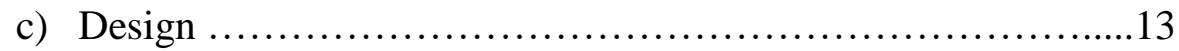

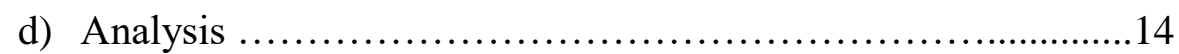

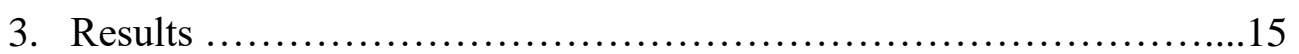

a) Parents' characteristics .................................15

b) Empathy............................................ 17

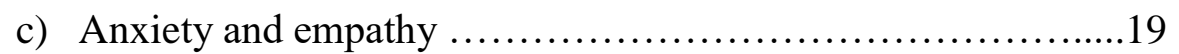

d) The effects of the other variables on parents' anxiety............21

e) Interviews Content Analysis ............................21

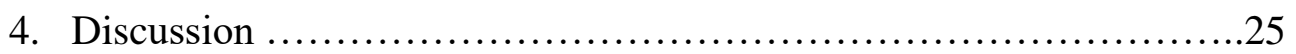

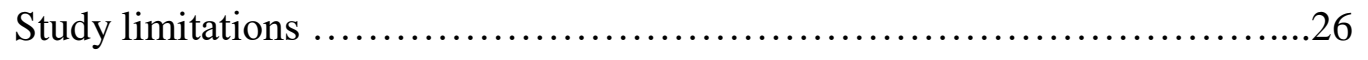

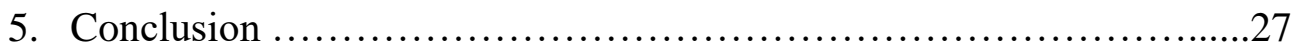

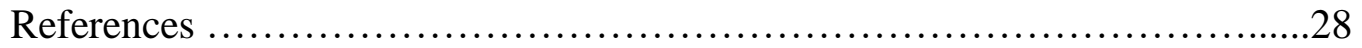

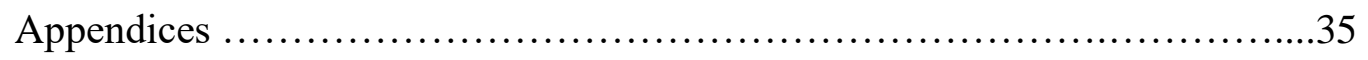

Appendix I ................................................ 36

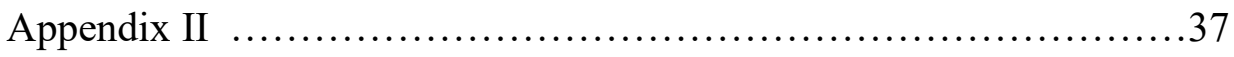

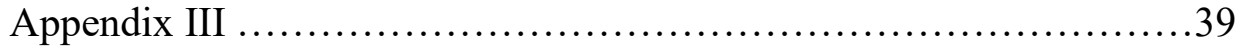

Appendix IV ..................................................40

Appendix V ...................................................42 


\author{
Abbreviations \\ PPCY - Promotion and Protection of Children and Youth \\ CPCY - The Commission for the Protection of Children and Youths \\ PR - Parental Responsibilities \\ CC - Civil Code \\ GMO - Guardianship of Minors Organization \\ RJ - Restorative Justice \\ IPCS - Integrated Program for Community Support \\ IRC - Integrated Response Centers \\ SRGD - Social Reintegration's General Direction \\ CMAT - Courts' Multidisciplinary Advisory Team \\ FMC - Family and Minors Court \\ HRA - Health Regional Administration \\ IDDAB - Intervention Department of Dependence and Addiction Behaviors \\ STAI-Y - State-Trait Anxiety inventory form Y \\ CARE - Consultation and Relational Empathy \\ SPSS - Statistical Standard Package for the Social Sciences \\ S - Screening \\ C - First Consultation \\ F - Father and $\mathbf{M}$ - Mother \\ SF - Stepfather \\ GF - Grandfather and GM - Grandmother
}




\begin{abstract}
Purpose. The aim of this study is to examine the effects of the professional's empathy on parents' anxiety and to explore parents' experiences of their current situations of PR, PPCY, and of the evaluation interview.
\end{abstract}

Methods. A cross-sectional assessment combines qualitative and quantitative methodology, was performed in 41 progenitors that have been submitted to requests of assessment processes, involving cases varying from Parental Responsibilities to Promotion and Protection of Children and Youth. This study includes individual semistructured interviews, non-participant observation and questionnaires: anxiety (StateTrait Anxiety inventory - STAI Y form 1 and 2, respectively) and empathy (Consultation and Relational Empathy questionnaire - CARE).

Results. Participants' anxiety decreased after the consultation. They perceived the empathy of the professionals who conducted the consultations to be greater than professionals themselves, though both rated overall professionals' empathy highly. Results showed that the only other variables in the model significantly influencing the decrease in parents' anxiety levels (besides empathy) were parents' trait anxiety and number of children.

Conclusion. In the context of juvenile criminology, parents' perceptions of professionals' empathy during evaluation interviews reduces their anxiety. In situations of potential loss of child custody, feelings of sadness and concern about the children future prevail in parents, along with worries about lacking the conditions to secure the custody of the child.

Keywords: Anxiety; Empathy; Parental Responsibilities; Promotion and Protection of Children and Youth; Juvenile Criminology. 


\section{RESUMO}

Objetivo. Este estudo tem por objetivo examinar a empatia dos profissionais na ansiedade dos progenitores, explorando as experiências dos mesmos nas situações de Responsabilidades Parentais, Promoção e Proteção de Crianças e Jovens, e nas entrevistas de avaliação.

Método. O estudo transversal de avaliação combina a metodologia qualitativa e quantitativa, sendo realizado em 41 progenitores que foram submetidos a um processo de avaliação, envolvendo casos de Responsabilidades Parentais e Promoção e Proteção de Crianças e Jovens. O estudo inclui entrevistas semi-estruturadas, observação não participante e os seguintes questionários: ansiedade (State-Trait Anxiety inventory STAI Y forma 1 e 2, respetivamente) e a empatia (Consultation and Relational Empathy questionnaire - CARE).

Resultados. A ansiedade dos progenitores diminuiu após as consultas. Os progenitores percecionaram uma maior empatia durante a consulta por parte dos profissionais do que os próprios auto percecionaram, embora ambos tenham classificado o nível de empatia como elevado. Os resultados mostram que a única variável que influencia significativamente a redução dos níveis de ansiedade, para além da empatia, foram o número de filhos e o traço de ansiedade dos progenitores (STAI formaY2).

Conclusão. No contexto da delinquência juvenil, a perceção dos progenitores face à empatia dos profissionais, durante as entrevistas de avaliação, reduz a sua ansiedade. Em situações da potencial perda da custódia da criança, prevalecem nos progenitores os sentimentos de tristeza e de preocupação com o futuro dos filhos, bem como a falta de condições para assegurar a custódia dos mesmos.

Palavras-chave: Ansiedade; Empatia; Responsabilidades Parentais; Promoção e Proteção de Crianças e Jovens; Delinquência Juvenil. 


\section{Introduction}

Parents can be required to undergo an evaluation that supports legal decisions about whether or not they keep the custody of their children. Parental Responsibilities (PR), understood in the interest and benefit of the children, are currently seen as a set of powers and duties of parents in relation to minor or non-emancipated children (articles 1885 to 1887 of the Civil Code), to ensure their material and moral well-being, their education ${ }^{1}$, their support, their legal representation and the administration of their goods and wealth (articles 1888 to 1900 of the CC). The assessment of parenting skills is usually requested when there are suspicions of abuse, mistreatment and/or child neglect, illegal substance abuse, or in cases of cognitive deficits and/or psychiatric disorders in parents who, in turn, endanger the well-being of the child (Budd et al., 2001). This evaluation ${ }^{2}$ is aimed at assessing the existence of a minimum level of parental competence that is sufficient to ensure the safety and well-being of the child (Budd \& Holdsworth, 1996) via tests "that the court deems necessary for the clarification of the personality and nature of family members and the dynamics of their mutual relations" (Epifânio \& Flour, 1997, p. 322). The process involves comparing clinical data and hypotheses with information gathered during the evaluation, allowing the description of each parent's behavior. The report sent to the court must always safeguard the best interests of the child and be based on scientific knowledge (Sotelo, Fariña \& Seijo, 2007). Only the court, through a reasoned decision, can declare that PR

\footnotetext{
${ }^{1}$ Parents have the duty and the right to raise and support their children (article 36, Portuguese Republic Constitution).

2 In this context, the courts preferably request the execution of psychological/forensic expertise (Machado \& Gonçalves, 2011), establishing itself as a key tool for judicial decision, assisting and supporting a more adequate intervention to the needs of the child or young person and the defense of their welfare (Martinho, 2011).
} 
be exercised by only one parent when the joint exercise - established as the rule of law - is deemed contrary to the interests of the child (Article 1906, p. 2, CC).

The object of Promotion and Protection of Children and Youth (PPCY) is the promotion of rights, and the protection of children and of youths at risk, to ensure their well-being and integral development (Protection Law of Children and Youth in Danger, 1999). The range of risks is broad in order to include the greatest possible number of cases that, regardless of nature and origin, compromise the fundamental rights of the child or youth and require the activation of protective intervention. This intervention should occur early, be minimal, proportional and contingent. That is, it should occur as soon as the danger is known and be exercised only by agencies whose action is essential for the effective promotion of the rights and protection of children and youths at risk. It must be necessary and appropriate to the actual risk at the time of the decision. The Commission for the Protection of Children and Youths (CPCY) is a non-judicial, interinstitutional and interdisciplinary official entity created to prevent dangerous situations, promote and protect children and youths at risk. Its measures in conjunction with the Courts are divided into two groups: (1) work developed with the parents, family member or significant other with whom the child or youth live in their natural living environment, and (2) placement measures (host family, host institution) (Protection Law of Children and Youth in Danger, 1999).

Like in a clinical act, situations of PR or PPCY involve the act of "waiting" for some event or for someone (Romano, 1997), with the several expectations, feelings and emotions that underlie it. According to Pereira and Matos (2011), in Portugal, the most frequently asked questions in the regulation of PR focus on "the assessment of personality and character of the family members and the dynamics of their mutual relations", as set out in article 178, p. 3, of the Guardianship of Minors Organization 
(GMO). According to the literature, evaluations are structured to ascertain whether the parent is able to provide a safe and stable environment that promotes the development of the child (Budd, 2001). These evaluations can lead to the withdrawal of the child from the family (Budd, 2001), thus possibly contributing to situations of anxiety in parents.

The way in which the evaluation interview is conducted can influence the amount and type of information obtained, and can simultaneously function as a response to parents' expectations and anxiety. The professional's empathic capacity can play an important role in this process, namely reducing the anxiety of the parents (who feel listened and understood), and possibly leading them to share more information.

There are numerous conceptions of empathy. Carl Rogers defines empathy as the ability to enter the world of the Other, of his or her feelings and opinions. Despite the conceptual variety, there is consensus about the fact that empathy is considered a significant and essential ability to establish relationships between individuals (Rogers, 1959). Norcross (2010) argues that empathy is associated with treatment success, allowing a smooth functioning of the therapeutic alliance, facilitating emotional experience, promotion, exploration and creation of meanings, and serving to support the development of self-regulation capacities in the person. In a situation of interaction, the empathic capacity can be conceptualized as occurring in two stages. The first, called empathic understanding, and the second, empathic communication (Falcone, 1999). According to Rogers, empathic understanding involves paying attention and listening, being sensitive to the feelings and personal reactions of the person (Rogers, 1961/1987). Empathic communication concerns the verbalization which shows to the individual that he or she was understood (Rogers, 1957/2008). It can also involve a non-verbal 
dimension, which is a process through which the observer mimics and synchronizes the emotional states of the Other, based on his or her facial expression, vocalization or posture (Preston \& De Waal, 2002).

Rogers (1959) highlights some difficulties in establishing empathy. The greatest barrier to interpersonal communication is the natural inclination to judge, assess, approve or disapprove of someone else's assertions. Understanding the perspective of the Other thus represents a position of risk and uncertainty in that it implies a departure from our frame of reference. The improvement of empathic capacity is an important contribution to the development of greater concern for others and to learn to place oneself from their point of view, which brings potential benefits to the interaction (Santos, 2011). Empathy has the power of opening communication channels to the relationship with the Other and has been associated with several positive results in various health centers, including increased degree of trust in the professional (Hojat, 2010), greater information sharing on the part of patients, greater satisfaction and reduction of anxiety (Beckman \& Frankel, 1984; Krznaric, 2015).

In the field of Criminology, there are numerous studies involving empathy. These include research related to psychopathy indicating that psychopaths have no conscience, empathy, guilt and remorse, factors that make them dangerous from a legal point of view and therefore important as objects of study (Kiehl \& Buckholtz, 2010). Some authors have related aggressive behavior with an empathy deficit, arguing that, by acting aggressively, the individual does not recognize the feelings of others, or is not moved by them (Barros \& Silva, 2006). Empathy also appears associated with reduction in aggressiveness, in the criminal domain (Davis, 1983). Several authors in other areas (Hoffman, 2001; Rogers, 2009) have also highlighted empathy as a key element of the individual's personality, as well as for improving interpersonal 
relationships (Jolliffe \& Farrington, 2011). Rosenberg (2006) developed the method of Nonviolent Communication, which authors call "empathic communication" and which consists of considering the values common to everyone involved, based on an empathic attitude. In this model, empathy has a central role in resolving conflicts in different situations, and it has been applied to Restorative Justice ${ }^{3}$ (RJ). The empathic bond is also fundamental in group meetings, from group therapy to self-help groups such as alcoholics anonymous, narcotics anonymous and their families (Yalom \& Leszcz, 2006). In a different area, Falcone (1999) points out that programs that focus on promoting the development of skills, where empathy is included, can and should be taught in schools as a preventive resource. The difficulty of children to "place themselves in the place of the Other" will make it easy for them to have aggressive attitudes, will contribute to the lack of the notion of the damage that their actions cause to the Other's self-esteem and well-being, and will lead to the difficulty to take responsibility for their actions (Santos, 2011).

Less attention has been paid to the role of professionals' empathy in clinical Criminology, in situations of PR and of PPCY. Studies in other clinical areas, namely in health care, report positive effects of professionals' empathy on reduction of anxiety and even on improvement of biological markers (Hojat et al., 2011; Rakel et al., 2011; Derksen et al., 2013.; Lobb et al., 2004; van Dulmen \& van den Brink-Muinen, 2004; Gallese, 2003; Verheul et al., 2010; Vedsted \& Heje, 2008; Pereira Figueiredo, Braga \& Carvalho, 2016). In addition to being one of the most humanistic dimensions mentioned in medicine (Linn et al., 1987; Arnold, 2002), empathy is also associated

\footnotetext{
${ }^{3} \mathrm{RJ}$ is a relatively new chain in the areas of victimology and criminology. Emerged in the mid-70s, rises associated with the proclamation of the failure of the so called retributive justice, unable to give adequate responses to crime and the specific problems of victims and offenders. RJ is a process through which parties to a crime decide together how to deal with the effects of the process and its future consequences (Reverby, 2016).
} 
with better diagnosis and therapeutic results in the clinical setting (Hojat, 2007). For example, Pereira et al. (2016) concluded that a patient-centered empathic approach reduced patients' anxiety and increased their satisfaction with the quality of the information provided, therefore having a positive effect. Rosário (2010) advances that effective communication in intensive care units, when adapted to the ventilated patient, promotes their psychological well-being, effectively promoting the establishment of a sense of security. It leads to the reduction of suffering, anxiety and mitigates the stress caused by this crisis.

It is possible that, in clinical Criminology, the professional's empathy also contributes to reducing the anxiety of parents in situations of PR and PPCY. This study explores the role of empathy in a clinical criminal context that has received little attention, specifically the encounter for the evaluation interviews of parents in situations of RP and PPCY. The aim of this study is to examine the effects of the professional's empathy on parents' anxiety and to explore parents' experiences of their current situations of PR, PPCY, and of the evaluation interview.

\section{Methodology}

To examine the expectations and the levels of anxiety of parents in situations of PR and PPCY, this study was conducted in the Integrated Program for Community Support (IPCS) and includes problematic situations of families from the Oporto metropolitan area. The IPCS intends to serve and support children, young people and families or other people involved. In order to minimize the risk factors and to acquire personal and social skills, considered as protective factors in the context of a consultation space (individual, family or group) when necessary to child psychiatry 
consultations. The routing and monitoring of the patient is operated in accordance with the requests made. These have different origins and may be self-referenced (patient demands IPCS to avail their services) or straight-referenced (referred by other entities).

There are several entities that use IPCS, such as schools, Integrated Response Centers (IRC), institutions (foster homes and shelters), social security through Social Reintegration's General Direction (SRGD), the Courts' Multidisciplinary Advisory Team (CMAT), the Commission for the Protection Children and Youths (CPCY), the Family and Minors Court (FMC), prisons and police stations, hospitals and health centers. Screening is the first service provided by professionals. It aims the initial evaluation, selection and referral of patients to the units, appropriate to their assistance (Azevedo \& Barbosa, 2006). It is expected to be a rich collection of data regarding the over mentioned problem. These consultations are intended to explore the personal and familial history of the patient, as well as carry out an assessment. The evaluation is an important tool allowing to analyze a situation, understanding it, and interpreting the general characteristics of reality (Guerra, 2000). After the screening, the cases are redirected to the professionals in the relevant area, and thus submitted to a first consultation. Until this time the IPCS is the only institution in Portugal that gives this kind of answers and offers the practical and scientific characteristics that were above mentioned.

\section{a) Sample}

The sample includes 41 invited participants who received verbal and written information about the study. The sample consists of progenitors who have been requested to undergo assessment processes for situations that ranged from PR to PPCY. We selected parents (or significant others holding the guard of the minor) who had 
never had previous contacts with the institution (IPCS) or the professional conducting the assessment interview. Those who agreed to participate signed a written term of informed consent.

Half of the participants were women, and most were the parents of the minor, only three being, respectively, grandmother, grandfather and stepfather. The term 'parent', used through the text, includes all four types of kinship, without distinction. They attended either screening appointments (14 parents) or their first evaluation consultations (27 parents). Screening and evaluation consultations are similar in that they involve the collection of personal data through face-to-face interviews, and parents were unaware that screening interviews are not the actual evaluation consultation. The sample's characteristics are presented in Table 1.

The professionals conducting the interviews were three women (with ages raging between 37 and 45 years old) with backgrounds in Social Education and Psychology. They had a mean work experience of 17 years and receive an average of 35 cases per week. They were informed about the study and agreed to participate.

The data are strictly confidential and anonymous, with a code assigned to each case. The study was approved by the head of IPCS, the Health Regional Administration (HRA) and the regional Coordinator of the Intervention Department for Dependence and Addiction Behaviors (IDDAB).

\section{b) Instruments}

For data collection, we used the following instruments: a questionnaire containing socio-demographic data, the State-Trait Anxiety Inventory (STAI Y form 1 and 2, respectively), the Consultation and Relational Empathy questionnaire (CARE), semi-structured interview and non-participant observation. 
The socio-demographic questionnaire includes participants' sex, age, education, work status, number of children, people in the household, residence, nationality, and previous contacts with the justice system.

The State-Trait Anxiety Inventory form Y (STAI-Y) is a 20-item self-report instrument which includes separate measures of state and trait anxiety. The original STAI form was originally made by Spielberger et al. (1983) and it was translated into more than 30 languages for cross-cultural research and clinical practice. It is a personal account of the instrument where the individual responses vary from "nothing" to "very", a rating scale from 1 to 4 which reflects the degree of anxiety, and (1) nothing; (2) little; (3) moderately and (4) very. There are however some items where the rating is reversed, they are numbers $1,2,5,8,10,11,15,16,19,20,21,23,26,27,30,33,34,36$ e 39 . Items (1 to 20) of the State Anxiety Inventory (STAI form Y 1) assess how the respondents feel when they respond to the inventory. Items (21-40) of the Trait Anxiety Inventory (STAI form Y 2) assess how they generally feel, causing them to conduct an assessment of the frequency of their feelings of anxiety. The calculation of the results is obtained by adding the points of each item, for each subscale, with the minimum score 20 and the maximum 80 . A higher score indicates a higher anxiety state-trait, for each situation. The choice of instrument is due with the fact that allows the evaluation of the anxiety as trait and the anxiety as a state. Another advantage of this questionnaire is related to the fact that it was studied for the Portuguese population, after due adaptation and assessment by the authors Santos \& Silva (1997); Silva \& Campos (1998); Silva et al. (1999/2000). These studies point to satisfactory values, they agree with the internal consistency of the appropriate instrument for the Portuguese population, and internal consistency of the STAI form Y was determined by Cronbach's 
alpha coefficient, which range between 0.88 and 0.93 , while a group in its first study had shown only a value of 0.77 .

The Consultation and Relational Empathy questionnaire (CARE) was developed by Stewart Mercer and colleagues in the Departments of General Practice at Glasgow and Edinburgh University. It is based on a broad definition of empathy in context of a therapeutic relationship. The scoring system for each item is 'poor' $=1$, 'sufficient' $=2$, 'good' $=3$, 'very good' $=4$, and 'excellent' $=5$. All ten items are then added, giving a maximum possible score of 50, and a minimum of 10 . It is only allowable up to two 'not applicable' responses or missing values, otherwise questionnaires are removed from the analysis. The CARE questionnaire depends on the observation of empathic behavior, not the self-report, referring to a simple scale comprising 10 items, directed towards empathic behavior. The questionnaire uses the patient's perception about the professional attitude of the consultation (Mercer et al., 2004).

The semi-structured interview is targeted at obtaining individual processes and experiences in the first person, including feelings, emotions, expectations and changes in life. The interview is the most used technique in the fieldwork process for data collection. According to Bogdan \& Biklen (2010) an interview is used to collect descriptive data in the subject's own language, allowing the researcher to intuitively develop an idea of how subjects interpret aspects of the world. Our interview included 10 open questions to explore parents' experiences and associated feelings, expectations, and changes in life.

Finally, we used non-participant observation to register the verbal and non-verbal interactions between parents and the professionals who conducted the evaluation interviews. The observer attended all the appointments, taking field notes. Observation is the manifest of the ability to see, to examine and record information, including what 
happens in the "field", description of the subjects, behaviors and reconstruction of dialogues (Patton, 1990).

\section{c) Design}

This cross-sectional study combines qualitative and quantitative methodology, and includes individual semi-structured interviews, non-participant observation and questionnaires (all lasting approximately one hour and fifteen minutes). The study comprises three stages of data collection: immediately before the technical evaluation (or screening) interview (T0), during the interview (T1), and immediately after the interview (T2).

At the moment T0, participants answered a socio-demographic questionnaire and a questionnaire to measure their level of anxiety (STAI form Y 1 and 2). At the moment T1, the researcher conducted non-participant observation during the consultations, taking filed notes. At the final moment (T2), parents answered the questionnaire to assess their level of anxiety again (STAI form Y1) and also the questionnaire measuring the professional's empathy (CARE). The professionals conducting the consultations also filled in the CARE questionnaire at this moment, to evaluate their own empathy. Finally, the researcher conducted individual semi-structured interviews with the parents. The study design and evaluation procedures are detailed in Figure 1. 


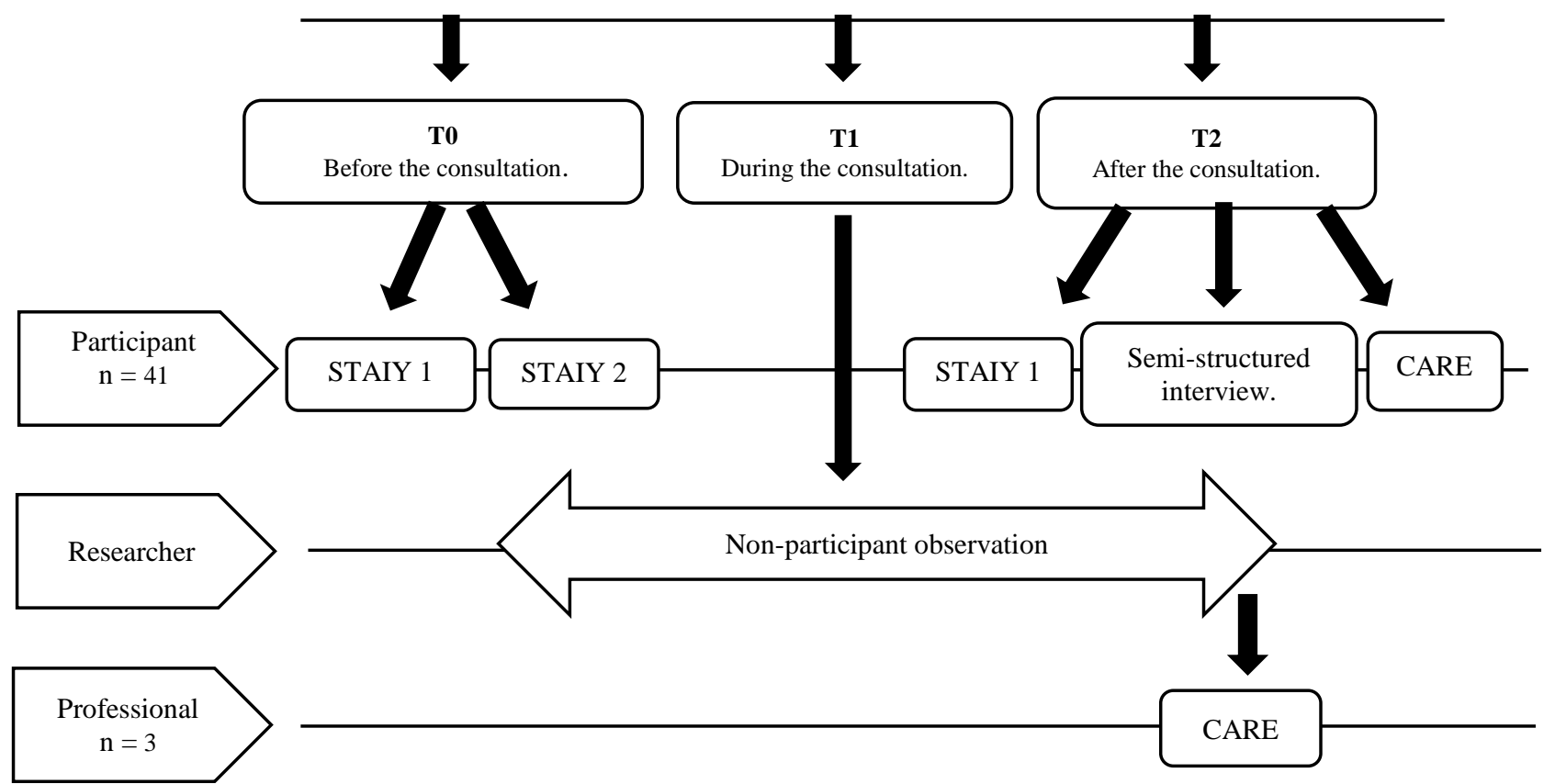

Figure 1. Study design and evaluation procedures.

\section{d) Analysis}

Quantitative data from the questionnaires were analyzed statistically in $I B M$ SPSS Statistics, version 22.0. A descriptive analysis was performed on the variables (means, standard deviations, frequencies and ranges), and $t$-tests were applied to compare mean values. A $p$ value $\leq 0.05$ was considered significant. We used General Linear Model Repeated Measures to assess the effects of empathy on anxiety changes from time 0 to time 2 . To this end, empathy scores were dichotomized into "perfect" empathy (only empathy scores $=50$, the maximum possible score) and "less than perfect" empathy (empathy scores $<50$ ). Co-variables included in the model were parents' trait anxiety (mean levels), age (mean number of years), gender, years of school (1-6, 7-12, and more than 12), work status (employed or not), number of children (1-6), and type of consultation (screening or first evaluation appointments). Only one parent had previous contacts with the justice system, and therefore we did not consider 
this variable. We also did not include the degree of kinship for similar reasons, or the institutions requesting parental evaluation because it is a nominal variable. However, Kruskal-Wallis tests showed no statistically significant differences in parents' trait or state anxiety among these institutions, before or after the appointments.

Regarding content analysis of the interviews, the encoding process was done by two independent people that came to a consensus agreement. The qualitative result for the semi-structured interviews was analyzed by use of content analysis, which is "a set of communications analysis techniques to obtain by systematic procedures and description of the contents of messages objectives, indicators that allowed the inference of knowledge of the conditions of production/reception" (Bardin, 2009, p. 44).

\section{Results}

\section{a) Parents' characteristics}

The trait anxiety of parents in this sample registered a medium value in the anxiety (Table 1). Ages ranged between 26 and 66 years old (mean=41.5; SD=9.6), and about half of the participants were women (51.2\%). Most had between six and nine years of school, and $53.7 \%$ were currently employed. Most were past the screening phase, attending first consultations $(65.9 \%)$. Their evaluations were mostly requested by the Commission for the Protection of Children and Youths (CPCY), and only one participant had a previous contact with the justice system. Most had only one child $(61 \%)$. 
Table 1. Characteristics of the parents $(\mathrm{N}=41)$.

\begin{tabular}{|c|c|c|c|c|}
\hline \multicolumn{2}{|l|}{ Characteristics } & Mean & $\begin{array}{l}\text { Standard } \\
\text { Deviation }\end{array}$ & Range \\
\hline \multicolumn{2}{|l|}{ Trait anxiety $^{a}$} & 46.6 & 10.8 & $27-66$ \\
\hline \multirow[t]{2}{*}{ Age (years) } & & 41.5 & 9.6 & $26-66$ \\
\hline & & $\mathrm{n}$ & $\%$ & \\
\hline \multicolumn{5}{|l|}{ Sex } \\
\hline & Men & 20 & 48.8 & \\
\hline & Women & 21 & 51.2 & \\
\hline \multicolumn{5}{|c|}{ Education (years) } \\
\hline & $4-6$ & 18 & 43.9 & \\
\hline & $7-12$ & 18 & 43.9 & \\
\hline & $>12$ & 5 & 12.2 & \\
\hline \multicolumn{5}{|l|}{ Work status } \\
\hline & Employed & 22 & 53.7 & \\
\hline & Unemployed & 19 & 46.3 & \\
\hline \multicolumn{5}{|c|}{ Degree of kinship with minor } \\
\hline & Father & 18 & 43.9 & \\
\hline & Mother & 20 & 48.8 & \\
\hline & Stepfather & 1 & 2.4 & \\
\hline & Grandfather & 1 & 2.4 & \\
\hline & Grandmother & 1 & 2.4 & \\
\hline
\end{tabular}

Type of consultation

$\begin{array}{lcc}\begin{array}{l}\text { Screening } \\ 1^{\text {st }}\end{array} & 14 & 34.1 \\ \text { Consultation } & 27 & 65.9\end{array}$

Evaluation request by

$\begin{array}{lcc}\text { CPCY }^{\mathrm{b}} & 17 & 41.5 \\ \text { CMAT }^{\mathrm{c}} & 9 & 22.0 \\ \text { SRGD }^{\mathrm{d}} & 7 & 17.1 \\ \text { FMC }^{\mathrm{e}} & 8 & 19.5\end{array}$

No. of contacts with justice

$\begin{array}{ccc}1 & 40 & 97.6 \\ 2 & 1 & 2.4\end{array}$

No. of children

$\begin{array}{ccc}1 & 25 & 61.0 \\ 2 & 12 & 29.3 \\ 3 & 2 & 4.9 \\ 6 & 2 & 4.9\end{array}$

\footnotetext{
aAssessed with the STAI Y2 on a 1-4-point scale (maximum score $=80$, representing the highest level of anxiety).

${ }^{\mathrm{b}}$ Commission for the Protection of Children and Youths.

'Courts' Multidisciplinary Advisory Team.

dSocial Reintegration's General Direction.

${ }^{\mathrm{e}}$ Family and Minors Court.
} 


\section{b) Empathy}

In general, parents perceived the empathy of the professionals who conducted the consultations to be greater than professionals themselves, though both rated overall professionals' empathy highly (Table 2). These results are reflected in the qualitative interviews with the parents. For readability purposes, the qualitative interviews are identified with the number of parents coded in each category, followed by type of encounter (Screening $-\mathrm{S}$, or first evaluation Consultation $-\mathrm{C}$ ), and by degree of kinship (Father - F, Mother - M, Stepfather - SF, Grandfather - GF and Grandmother - GM).

Most parents stated that, during the appointment with the professional, they felt "fearful" of the decision [1S, F] and "nervous/anxious" ("I could be misinterpreted" [1S, F]; "CPCY technicians are bad, I was nervous until I saw that the doctor was on my side" [4C, F, M]). However, parents left the consultation feeling "good" [12S, F, M; 19C, F, M], "heard" [2S, M; 4C, F, M], "understood" [1S, F; 2C, M], "relieved" for having the chance of venting their situations to someone who listened [1S, M; $1 \mathrm{C}, \mathrm{M}]$, and "at home" [1C, F]. One father who had regained the right to his son's visits every other week felt "moved" [1S, F]. Almost all parents considered that the consultation corresponded to their expectations (38 interviews [14S; 24C]: "You are very kind, doctor, and you make me feel good" $[1 \mathrm{~S}, \mathrm{~F}]$. Those who reported that the interview did not correspond to their expectations had a positive experience ("It didn't correspond because I thought that the doctor was going to do some kind of [urine] test and I was uncomfortable with it, whew!" [1S, F]; "I thought that the doctor was going to decide whether or not I'd lose parental custody, but it didn't happen, so it's better this way" $[1 \mathrm{C}, \mathrm{F}])$. 
Field notes from non-participant observation also corroborate the idea that these professionals were highly empathetic in their communication during the consultation, offering support and reassurance in response to parents' distress ("You don't have to apologize"; "I imagine that it's really complicated to deal with this situation all alone"; "I'm here to help you as best as possible"; "and, together, understand why this is happening, I know it's not easy"; maintaining eye contact when responding empathically, or placing one hand on the parents' arm when she started to cry, and respecting parents' silence until they pulled themselves together).

Parents and professionals agreed that the professionals' empathy was greater in screening than in first consultations. These results are depicted in Figure 2. The difference in empathy between the two types of consultations was statistically significant in parents' assessments $\left(t_{(34)}=4.886 ; p=0.000\right)$ and marginally significant in professionals' self-assessments $\left(t_{(21)}=2.070 ; p=0.051\right)$.

Table 2. Professionals' empathy assessed by the parents and self-assessed by the professionals in two different types of consultations.

\begin{tabular}{lccc}
\hline $\begin{array}{l}\text { Empathy } \\
\text { (standard deviations) }\end{array}$ & $\begin{array}{c}\text { Screening } \\
\text { consultations }\end{array}$ & $\begin{array}{c}1^{\text {st }} \\
\text { consultations }\end{array}$ & Overall \\
\hline Parents' assessment & 49.36 & 44.22 & 45.9 \\
& $(1.50)$ & $(5.05)$ & $(4.8)$ \\
Professionals' self-assessment & 42.93 & 40.33 & 41.2 \\
& $(4.14)$ & $(3.06)$ & $(3.6)$ \\
No. of encounters & 14 & 27 & 41 \\
\hline
\end{tabular}

${ }^{\mathrm{a}}$ Assessed with the CARE on a 1-5-point scale (maximum score $=50$, representing the highest level of empathy). 


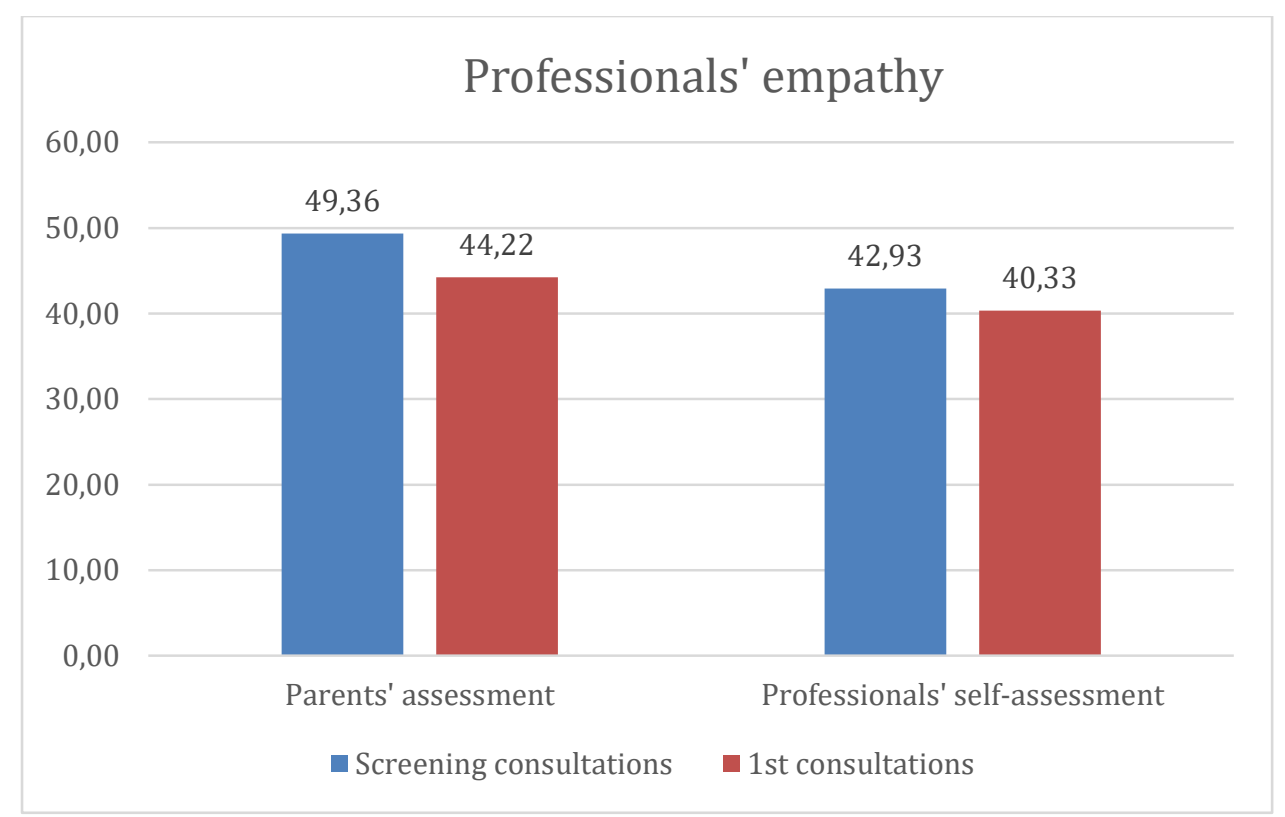

Figure 2. Professionals' mean levels of empathy as assessed by parents and by professionals themselves (self-assessment) in two different types of encounters (screening and first consultations).

\section{c) Anxiety and empathy}

Participants' anxiety decreased after the consultation (Table 3). General Linear Model Repeated Measures revealed that the effect of the professionals' empathy on this decrease was statistically significant (Figure 3 ), $z_{(1)}=6.447 ; p=0.016$, showing that the decrease in parents' anxiety was greater when professionals had a 'perfect' score in empathy than when professionals had a 'less than perfect' empathy score ( $t$-tests showed that the levels of anxiety of the parents with 'perfectly' empathetic professionals and with 'less than perfectly' empathetic professionals were similar, with non-significant differences, before the appointment with the professionals, and these results applied to both trait and state anxiety).

These significant effects were observed only for professionals' empathy as perceived by parents. Professionals rated their own empathy as 'perfect' only in five 
appointments. Their perceptions of their own empathy did not yield significant effects on the decrease in parents' anxiety.

Table 3. Parents' anxiety before and after the consultations (means and standard deviations).

\begin{tabular}{lccc}
\hline & $\begin{array}{c}\text { Before the } \\
\text { consultation }\end{array}$ & $\begin{array}{c}\text { After the } \\
\text { consultation }\end{array}$ & $\mathrm{N}$ \\
\hline Overall & 47.9 & 36.9 & 41 \\
& $(11.9)$ & $(8.9)$ & \\
With a 'perfect' empathy professional & 48.20 & 33.95 & 20 \\
& $(13.88)$ & $(7.24)$ & \\
With a 'less than perfect' empathy professional & 47.52 & 39.62 & 21 \\
& $(10.04)$ & $(9.53)$ & \\
\hline
\end{tabular}

${ }^{\mathrm{a}}$ Assessed by parents with the STAI Y1 on a 1-4-point scale (maximum score $=80$, representing the highest level of anxiety).

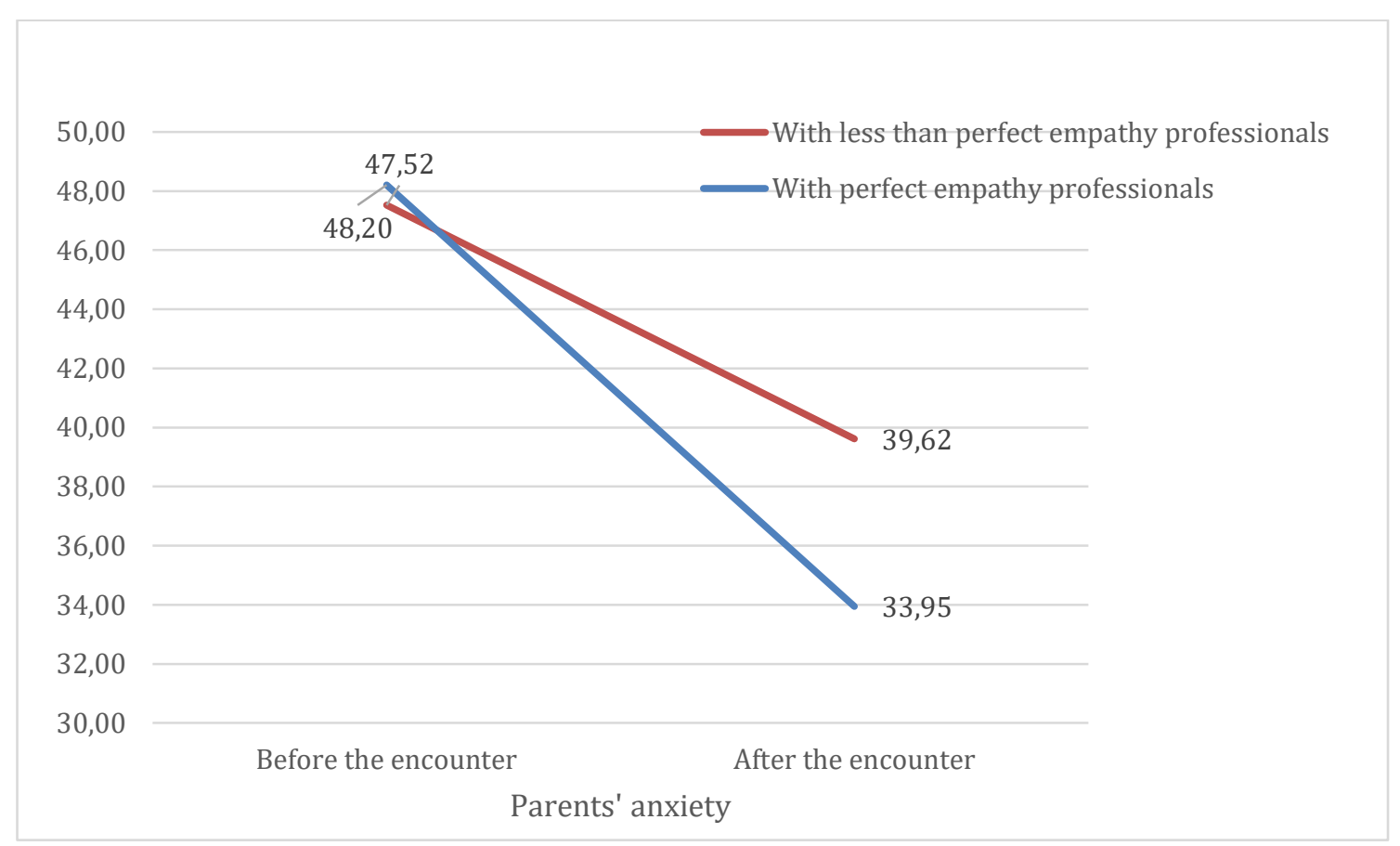

Figure 3. Parents' anxiety before and after consultations with either 'perfect' or 'less than perfect' empathy professionals (as perceived by parents). 


\section{d) The effects of the other variables on parents' anxiety}

Results also showed that the only other variables in the model significantly influencing the decrease in parents' anxiety levels were parents' trait anxiety $\left(z_{(1)}=22.810 ; p=0.000\right)$ and number of children $\left(z_{(1)}=5.727 ; p=0.023\right)$. The effects of the other variables on the decrease in parents' anxiety were non-significant (parents' age, gender, years of school, work status, number of children, and type of consultation, whether screening or first evaluation appointments).

\section{e) Interviews Content Analysis}

The analysis of the interviews revealed several themes illuminating the experiences parents have when confronted with situations in which they can lose the custody of their children, and with the encounters required for the evaluation of these situations.

In responses to question one of the interviews, "What was your reaction when you found out that you can lose your child custody?", three major themes emerged: "Types of Reactions", "Feelings" and "Justifications". Regarding "Types of Reactions", 17 people qualified their reaction as "terrible" [4S, M, F; 4C, M, F], "poor" [1S, F; 1C, F], "bad" [2S, M], "awful" [1S, F; 2C, M], or said that they cried [2C, M]. Others mentioned their "Feelings". "Sadness" and variations (e.g., depression) were the most prevalent feelings (in 24 interviews [7S, M, F; 19C, M, F]). Another recurring feeling (in 19 interviews) was "fear" [4S, M, F; 2C, M, F], "nervousness" [1S, F; 2C, M, F], "anxiety" [3C, M, F], "anguish" [2S, M; 2C, M, F] and "panic" [1S, M; 2C, M]. "Distress" ("not knowing what to do" [4S, M, F; 2C, M], "without knowing why" [1S, F; 2C, F]), and "impotence" ("I need help" [1S, M; 2C, M], "I am disoriented", "I don't 
know what to do" [1S, F; 4C, M, GM, GF]) emerged in 17 interviews. "Revolt" and "irritation/anger" ("I was furious with this injustice," "it is unthinkable to lose a child") was also common [10C, F, M]. Other, less often mentioned feelings were "disappointment" with the children's drug behaviors [2C, M, F], "feeling wronged" ("It was an injustice because CPCY only acts as a last resource, and in my case they immediately considered taking my daughter away ... with only one episode" [1S, M; 1C, M], "shame" [2C, M] and "love for the son" [2S, F]. Finally, parents offered Justifications for the situations (17 interviews), associated with a variety of difficulties: "troubled children" [3S, M, F; 2C, M, GM], "I work a lot" [2S, F; 3C, M, F], "I'm unemployed" [1S, F; 1C, F], "I have many children" [1C, M], "I don't have the means to have my son with me" [1S, M], or "parents' early separation" [2S, M, F; 1C, F].

Responses to the question on "What has changed in your life?" were greatly varied, and changes were great in many cases. Increased levels of "stress" [4T, M, F; 1C, F], "concern" [1S, F; 4C, M, F] and "nervousness" [2S, M; 6C, M, F] were the most frequently mentioned changes. "Health" was also affected ("my health worsened" [1C, M], "I had a relapse in my disease" [1C, M], "I had already had a stroke and now I'm even worse" [1C, F], "bad sleep, ill with headaches" [1S, M; 2C, M, F], "overthinking" [1C, F] and "restless, agitated" [2C, F]). "Work" changed too ("I work more hours to unwind" [1S, M], "I work more hours for more income to be able to support my family" [2C, F], "Now, I can't work" [2S, M] and "I work less to pay more attention to, and accompany my son" [1C, M]). "Alertness" ("I am more aware", "I gained more awareness of reality" [2S, M; 2C, M, F] and "I'll be better person" [1C, M]). Other changes were: increased "fear" ("I'm more scared" [3S, M; 1C, M], "everything changed" [2S, M; 1C, F] and "I see [the institutionalized child] less often" [2S, F; 1C, $\mathrm{M}]$ ). Changes also occurred to escape public scrutiny ("I changed my residence" [1S, 
$\mathrm{M}]$, "I changed my workplace" [1S, M], "the neighbors intrude in our lives" [1C, F]). Less frequently mentioned changes were the sense of "rejection of, or by the child" ("[my son] says that I don't want him anymore" [1T, F], "now, [my son] does not like $m e "[1 \mathrm{C}, \mathrm{F}]$ and "regret" for not having prevented the situation ("I never thought it would come to this" [2C, M]).

Responses to the question on "What are your main concerns?" were also varied. The child's well-being was a recurring concern for parents, mentioned in 22 interviews ("with his future" [3S, M, F; 6C, M, F], "I do not want him to suffer more with this process" [2S, M; 5C, M, F], "that he is calmer and less aggressive" [3S, M; 3C, GM, GF, M]). Children's involvement in illegal activities was also a major concern for parents, emerging in 16 interviews ("I do not want him to continue in a bad life or with bad influences from outlaws" [2S, M; 6C, M, F], "I wish he leaves that kind of bad behavior" [1S, M; 3C, M, F], "to get out of addiction" [2C, F], "that he does not steal anymore" $[1 \mathrm{C}, \mathrm{F}]$ and "I prefer a detained son than a drugged one" $[1 \mathrm{~T}, \mathrm{M}])$. This concern is well illustrated in the following excerpt, "I already promised I'll give him anything he wants if he promises to leave the wrong track. It's disquieting, a tightness in the heart, I can never be calm". Another common concern (appearing in 10 interviews) had to do with "child's obedience" ("I can't control him" [1S, M], "he does not obey me" [3C, GM, GF, M], "he disobeys me in public" [2C, GM, M], "he disobeys teachers in school" [3C, M, F] and "I do not know how to handle him and I am his father" [1S]). Lack of "recognition of the parental figure" was mentioned in six interviews ("I hope that my son likes me" [2S, F] and "I want him to see me as a father" $[2 \mathrm{~S} ; 2 \mathrm{C}])$. This concern is well illustrated in the following excerpt, "I already promised I'll give him anything he wants if he promises to leave the wrong track. It's disquieting, a tightness in the heart, I can never be calm". Other concerns included lack of 
conditions to secure the custody of the child ("I continue being unemployed" [2S, F; 2C, M, F], "our environment at home is heavy" [1S, M; 1C, M] and "I am a sick person and I have to take care of my health" [1S, M; 1C, GM]). Other concerns reported less often were the wish to "Bring the family together" ("I want us to be closer" [1S, M], "closer to the grandmother" [1C, GF]) and to be with the children ("I want to see my children grow up" [2C, M]). One father whose son was institutionalized and whose wife had recently lost an unborn baby expressed the concern of "having another child" $[1 \mathrm{C}, \mathrm{F}]$.

Parents' most common response to the question, "What are your fears?" was "loss of parental custody" ("losing my parental rights" [3S, M, F; 11C, M, F], "I'm afraid that my child goes to an institution" [3S, M, F; 2C, M, F]) emerging in 19 interviews. Next (mentioned in 18 interviews), parents were afraid that their children were on an irreversible path ("I'm afraid she is lost again" [3S, M; 2C, M, F], "that she doesn't recover anymore" [3C, $\mathrm{M}]$, "that he takes the wrong way", $[2 \mathrm{C}, \mathrm{M}, \mathrm{F}]$, "that he continues drug dealing and using" [2C, $\mathrm{M}]$ and "that he does not end the treatment" [2C, M, F]) that would lead to prison ("that he is arrested" [2S, M, F; 3C, M, F]). The third most frequently mentioned fear (appearing in 18 interviews) was lack of "control over the child" ("that I have no control over him" [1S, M; 1C, M], "he still does not obey me" [2C, GM, M], "I fear she continues with disciplinary offenses in school and disobeying teachers" [2C, M], "of not knowing how to deal with my child" [1C, F] and "of not knowing how to properly raise him" [2C, F]) and lack of help ("I don't have external help" [1S, F]). Lack of conditions to secure the custody of the child emerged again ("that I become/remain unemployed" [4S, M, F; 2C, F]).

Other fears were verbalized less frequently, including the fear that the daughter commits suicide after her threats, should the parents not be together as a couple again 
$[1 \mathrm{~S}, \mathrm{M}]$, "to stay alone" if the child is institutionalized or under the custody of the other parent $[3 \mathrm{C}, \mathrm{M}, \mathrm{F}]$, or if something happens to the company ("my husband has had a stroke" [1S, M]), and, again, of lack of "recognition of, and lack of positive feelings toward the parental figure" ("He says I am worthless" [1S, M], "she wishes me to die" [1C, F] and "that my child stops liking me" [2C, M, F], "health", "my health, because I have not been feeling good" [2C, M]). One parent had "no fears" [1C, F].

\section{Discussion}

This study inspected the relationship between the anxiety of parents whose child custody is under evaluation and the empathy of the professionals conducting the evaluation interviews. In general, parents considered professionals to be highly empathetic, and even more so in the screening interviews. Our results indicate that the professional's empathy affects parents' anxiety. Mean anxiety levels significantly decreased after the evaluation appointment for all parents (several explained how they were initially "anxious" and "afraid", but "felt better" after the interview, namely because their fears did not materialize at that moment). However, this decrease was significantly higher (and with less variation) for parents paired with professionals who had a "perfect" score in empathy than for parents paired with professionals who had a "less-than-perfect" score in empathy. These results reinforce the importance of empathic communication in justice-related contexts and add to findings observed in other clinical areas also suggesting that empathic communication has positive effects on the person's anxiety (van Dulmen \& van den Brink-Muinen, 2004; Verheul et al., 2010; Vedsted \& Heje, 2008; Pereira et al., 2016). Professionals' empathy is directly related with anxiety reduction (Derksen et al., 2013), and patients consider empathy as 
the basic component of all relationships (Mercer et al., 2002; Irving \& Dickson, 2004). Empathic relationships are associated with greater satisfaction and adherence to prescriptions, and to increased trust between the person and the professional, which can also lead to greater sharing of information (Beckman \& Frankel, 1984; Kim, Kaplowitz, \& Johnston, 2004; Hojat, 2010).

Our sample comprised both men and women with a wide range of ages. Some were highly educated, others were less educated, some were unemployed whereas others had steady jobs. These aspects had non-significant effects on parents' anxiety after the consultation. Only empathy (as well as parents' trait anxiety and number of children) had a significant influence on the anxiety after the consultation.

\section{a) Study limitations}

This study was conducted with a small sample of parents under evaluation for child custody at one center. Studies with larger samples that include more centers can cast further light on the results, namely regarding the effects of socio-demographic variables on parents' anxiety levels. Because the evaluation of parental custody is a critical situation, the possibility of social desirability cannot be excluded from parents' responses, despite our careful procedures (e.g., explaining that we and the study were external to the system, that all data were anonymous and strictly confidential, and building a rapport). The professionals conducting the evaluations might also have changed their behaviors as a result of knowing that they were being observed. If that was the case, the analyses still showed significant differences between higher and lower empathy levels, even when empathy rates were all high. We triangulated techniques of data collection, using a qualitative approach to complement the data from the quantitative piece, thus overcoming the limitations of responding to pre-defined 
phrases, inherent to questionnaires, and providing an understanding of parents' experiences in their own words. Future longitudinal studies are important to assess different moments of the process parents undergo in the institutions, and inspect the role of empathy on aspects such as parents' attendance in interviews.

\section{Conclusion}

Our results show that, in the context of juvenile criminology, parents' perceptions of professionals' empathy during screening and evaluation interviews reduces their anxiety. In situations of potential loss of child custody, feelings of sadness and concern about children prevail in parents, along with worries about lacking the conditions to secure the custody of the child. 


\section{References}

1. Arnold, L. (2002). Assessing professional behavior: yesterday, today, and tomorrow. Academic Medicine, 77(6), 502-15.

2. Azevedo, J. M. R., \& Barbosa, M. A. (2006). Triagem em serviços de saúde: Perceção dos usuários. Revista Enfermagem Uerj, Rio de Janeiro, 15(1), 33-9.

3. Bardin, L. (2009). Análise de Conteúdo. Lisboa: Edições 70.

4. Barros, P. B., \& Silva, F. B. N. (2006). Origem e manutenção do comportamento agressivo na infância e adolescência. Revista Brasileira Teorias Cognitivas, 2(1), 55-66.

5. Beckman, H. B., \& Frankel, R. M. (1984). The effect of physician behaviour on the collection of data. Annals of Internal Medicine, 101, 692-696.

6. Bogdan, R., \& Biklen, S. (2010). Investigação Qualitativa em Educação: Uma Introdução à Teoria e aos Métodos. Porto: Porto Editora.

7. Budd, K. (2001). Assessing parenting competence in child protection cases: A clinical practice model. Clinical Child and Family Psychology Review, 4(1), 118.

8. Budd, K., \& Holdsworth, M. J. (1996). Issues in clinical assessment of minimal parenting competence. Journal of Clinical Child Psychology, 25(1), 2-14.

9. Budd, K., et al. (2001). Clinical assessment of parents in child protection cases: An empirical analysis. Law and Human Behavior, 25(1), 93-107.

10. Davis, M. H. (1983). Measuring individual differences in empathy: Evidence for a multidimensional approach. Journal of personality and social psychology. 44(1), 113. 
11. Derksen, F., Bensing, J., \& Lagro-Janssen, A. (2013) Effectiveness of empathy in general practice: a systematic review. British Journal of General Practice, 63, 76-84.

12. Epifânio, R., \& Farinha, A. (1997). Organização Tutelar de Menores: Contributo para uma visão interdisciplinar do direito de menores e de família. Coimbra: Almedina.

13. Evertson, C., \& Green, J. L. (1986). Observation as inquiry and method. In Wittrock M. C. (Ed.), Handbook of research on teaching (3rd ed., pp. 162-213). New York: MacMillan.

14. Falcone, E. (1999). A avaliação de um programa de treinamento da empatia com universitários. Revista brasileira de terapia comportamental e cognitiva, $1(1), 23-32$.

15. Gallese V. (2003). The roots of empathy: the shared manifold hypothesis and the neural basis of intersubjectivity. Psychopathology jornal, 36(4), 171-180.

16. Guerra, Y. (2000). Instrumentalidade do processo de trabalho e serviço social. In Serviço Social \& Sociedade. São Paulo: Cortez, n. 62.

17. Hoffman, M. L. (2001). Empathy and moral development: Implications for caring and justice. Cambridge University Press.

18. Hojat, M. (2007). Empathy in patient care: antecedents, development, measurement, and outcomes. New York: Springer.

19. Hojat, M., Louis, D. Z., Markham, F. W., et al. (2011). Physicians' empathy and clinical outcomes in diabetic patients. Academic Medicine, 86, 359-364. 
20. Hojat, M., Louis, D. Z., Maxwell, K., et al. (2010). Patient perceptions of physician empathy, satisfaction with physician, interpersonal trust, and compliance. International Journal of Medical Education, 1, 83-88.

21. Irving, P., \& Dickson, D. (2004). Empathy: towards a conceptual framework for health professionals. Internacional Journal of Health Care Quality Assurance Incorporating Leadership in Health Service, 17(4-5), 212-220.

22. Jolliffe, D., \& Farrington, D. P. (2011). Is low empathy related to bullying after controlling for individual and social background variables. Journal of Adolescence. 34(1), 59-71.

23. Kiehl, K. A., \& Buckholtz, J. W. (2010). Inside the mind of a psychopath. Scientific American Mind, 21(4), 22-29.

24. Kim, S. S., Kaplowitz, S., \& Johnston, M. V. (2004). The effect of physician empathy on patient satisfaction and compliance. Evaluation \& the Health Professions, 27, 237-251.

25. Krznaric, R. (2015). Empathy: Why it matters, and how to get it. New York, NY: Perigree.

26. Linn, L. S., et al. (1987). Measuring physicians' humanistic attitudes, values, and behaviors. Medical Care, 25(6):504-15.

27. Lobb, E. A., Butow, P. N., Barratt, A., et al. (2004). Communicaton and information-giving in hgh-risk breast cancer consultations: influence on patient outcomes. British Journal of Cancer, 90, 321-327.

28. Machado, C., \& Gonçalves, R. A. (2011). Avaliação psicológica forense: Características, problemas técnicos e questões éticas. In M. Matos, R. A. Gonçalves, \& C. Machado (Coord.), Manual de psicologia forense: Contextos, práticas e desafios (pp. 15-29). Braga: Psiquilíbrios Edições. 
29. Martinho, G. (2011). Crimes sexuais contra mulheres adultas: Da avaliação forense à decisão judicial. Tese de Mestrado em Psicologia da Justiça da Escola de Psicologia da Universidade do Minho, Portugal.

30. Mercer, S. W., Maxwell, M., et al. (2004). The consultation and relational empathy (CARE) measure: development and preliminary validation and reliability of an empathy-based consultation process measure. Family Practice, 21(6), 699-705.

31. Mercer, S. W., \& Reynolds, W. J. (2002). Empathy and quality of care. The British Journal of General Practice. 52(suppl), S9-12.

32. Norcross, J. C. (2010). The therapeutic relationship. In B. L. Duncan, S. D. Miller, B. E. Wampold, \& M. A. Hubble (Eds.), The heart and soul of change: Delivering what works in therapy (2 ed.) (pp. 113-141). US: American Psychological Association.

33. Patton, M. (1990). Qualitative evaluation and research methods (2nd edition). London: (2nd edition). London: Sage Publications.

34. Pereira, A., \& Matos, M. (2011). Avaliação Psicológica das Responsabilidades Parentais no Casos de Separação e Divórcio. In M. Matos, R. Gonçalves \& C. Machado (Eds.). Manual de Psicologia Forense: Contexto, Práticas e Desafios (311-347). Braga: Psiquilibrios Edições.

35. Pereira, L., Figueiredo-Braga, M., \& Carvalho, I. P. (2016). Preoperative anxiety in ambulatory surgery: The impact of an empathic patient-centered approach on psychological and clinical outcomes. Patient Education and Counseling, 99(5), 733-8.

36. Preston, S. D., \& de Waal, F. B. M. (2002b). Empathy: its ultimate and proximate bases. Behavioral and Brain Sciences, 25(1), 1-71. 
37. Rakel, D., Barrett, B., Zhang, Z., et al. (2011). Perception of empathy in the therapeutic encounter: Effects on the common cold. Patient Education and Counseling, 85(3), 390-397.

38. Reverby, S. M. (2016). Restorative justice and restorative history for the sexually transmitted disease incoculation experiments in Guatemala. American Journal of Public Health, 106(7), 1163-4.

39. Rogers, C. (1959). Teoria da terapia, personalidade e relações interpessoais. In: Sigmund Koch, Psychology: A study of a science, vol. III, New York: McGrawHill.

40. Rogers, C. (1987). Tornar-se pessoa (2a ed.). (M. J. C. Ferreira, Trad.). São Paulo: Martins Fontes. (Original publicado em 1961).

41. Rogers, C. (2008). As condições necessárias e suficientes para a mudança terapêutica na personalidade. Em J. K. Wood, J. R. Doxsey, L. M. Assumpção, M. A. Tassinari, M. Japur, M. A. Serra, R. W. Rosenthal, S. R. Loureiro, \& V. E. Cury (Orgs.). Abordagem centrada na pessoa (4a ed., pp. 143-161). Vitória: EDUFES. (Original publicado em 1957).

42. Rogers, C. (2009). Tornar-se Pessoa. Lisboa: Padrões Culturais Editora.

43. Romano, B. W. (1997). A família e o adoecer durante a hospitalização. Revista da Sociedade de Cardiologia, Estado São Paulo, 7(5 Supl A), 58-62.

44. Rosário, E. (2010). Comunicação e cuidados de saúde. Comunicar com o doente ventilado em Cuidados intensivos. Dissertação de mestrado em comunicação em saúde, apresentada na Universidade Aberta. Lisboa.

45. Rosenberg, M. (2006). Comunicação Não-Violenta. Ágora, São Paulo.

46. Santos, E. G. (2011). Empatia e Bullying, em alunos do $4^{o}$ e do $6^{o}$ ano. Dissertação de Mestrado, Universidade de Lisboa, Lisboa, Portugal. 
47. Santos, S. C., \& Silva, D. R. (1997). Adapatção do state-trait anxiety inventory (STAI) - forma Y para a população portuguesa: primeiros dados. Revista portuguesa de psicologia, (32), 85-98.

48. Silva, D. R., \& Campos, R. (1998). Alguns dados normativos do inventário de estado-traço de ansiedade forma Y (STAI-Y) de Spielberger, para a população portuguesa. Revista portuguesa de psicologia, (33), 71-89.

49. Silva, D. R., et al. (1999/2000). Estudo de adaptação e estabelecimento de normas do inventário de Estado-Traço de ansiedade (STAI) -Forma Y de Spielberger para a população militar Portuguesa. Revista de Psicologia Militar, (12), 20.

50. Sotelo, A., Fariña, F., \& Seijo, D. (2007). Evaluación de custodias: Métodos e instrumentos. Revista Galega de Cooperación Cientifica Iberoamericana, 14, $30-43$.

51. Spielberger, et al. (1983). Manual for the State-Trait Anxiety Inventory. Palo Alto, CA: Consulting Psychologists Press.

52. van Dulmen, S., \& van den Brink-Muinen, A. (2004). Patients' preferences and experiences in handling emotions: a study on communication sequences in primary care medical visits. Patient Education and Counseling, 55(1), 149-152.

53. Vedsted, P., \& Heje, H. N. (2008). Association between patients' recommendation of their GP and their evaluation of the GP. Scandinavian Journal of Primary Health Care, 26(4), 228-234.

54. Verheul, W., Sanders, A., \& Bensing, J. (2010). The effects of physicians' affect-oriented communication style and raising expectations on analogue patients' anxiety, affect and expectancies. Patient Education and Counseling. 80(3), 300-306. 
55. Yalom, I. D, \& Leszcz, M. (2006). Psicoterapia de grupo: teoria e prática. Porto Alegra: Artmed.

\section{Legislation quoted:}

- Civil Code (articles from 1885 to 1887 and articles from 1888 to 1900).

- Protection Law of Children and Youth in Danger, 1999.

- Guardianship of Minors Organization (article 178).

- Portuguese Republic Constitution (article 36). 
Appendices 


\section{APPENDIX I}

\section{U.PORTO}

FMUP FACULDADE DE MEDICINA

UNIVERSIDADE DO PORTO

Questionário original para caraterização sociodemográfica

\begin{tabular}{|c|c|}
\hline \multicolumn{2}{|c|}{ Questionário de caraterização sociodemográfica } \\
\hline 1. Apresentação - Nome do Investigador/Profissão & \\
\hline 2. Importância do Investigador tirar notas & \\
\hline 3. Informar sobre a confidencialidade & \\
\hline $\begin{array}{l}\text { 4. Nome completo } \\
\text { (Sexo F/M) }\end{array}$ & \\
\hline 5. Data de Nascimento & $--^{\prime}--^{\prime}--$ \\
\hline 6. Residência & \\
\hline 7. Naturalidade & \\
\hline 8. Com quem habita? & \\
\hline 9. Habilitações Literárias & \\
\hline 10. Ocupação & \\
\hline 11. Número de filhos & \\
\hline 12. Contatos com a justiça (Consulta de processos) & \\
\hline
\end{tabular}




\section{APPENDIX II}

\section{U.PORTO}

FMUP FACULDADE DE MEDICINA

UNIVERSIDADE DO PORTO

\section{Guião de Entrevista Semiestruturada}

1. Quando descobriu que poderia ficar sem o(s) seu(s) filho(s), qual foi a sua reação?

Expetativas;

. Sentimentos associados.

Quando foi?

2. Como soube que poderia ficar sem ele(s)?

. Quem lhe deu a notícia?

Que tipo de informação lhe deram?

3. Depois de ter sabido, o que mudou na sua vida?

. Quais os motivos dessas alterações?

Como se sente em relação a isso?

\section{Quais são as suas principais preocupações?}

. Incapacidade de ficar com o(s) filho(s);

. Incapacidade de satisfazer as necessidades do(s) filho(s);

. Incapacidade de perceber as suas necessidades/compreensão do(s) seu(s) filho(s).

5. Quais são os seus medos?

Ficar sem o(s) filho(s);

Défices de comunicação;

. Incapacidade de resposta. 
6. Ao longo da consulta como se sentiu?

. Sentimentos;

. Opinião quanto à postura adotada pelo clínico;

. Compreensão empática.

7. E em relação àquilo que esperava para esta consulta, como corresponderam às expetativas?

. Corresponderam? Não?

8. Conte-me então como é agora um dia típico para si?

. Com quem faz essas atividades?

. Quais são? E aos fins-de-semana? Passatempos.

9. E antes, como era um dia típico para si?

10. Quer referir-me mais alguma coisa que não tenha sido abordada? 


\section{APPENDIX III}

\section{Consentimento informado}

Título do Projeto: A influência da empatia dos profissionais na ansiedade dos progenitores em casos de delinquência juvenil.

Investigador Principal: Juliana Canedo da Rocha

\section{Introdução/Objetivo:}

Este é um estudo do Serviço de Psicologia Médica da Faculdade de Medicina da Universidade do Porto que visa avaliar o grau de ansiedade e expetativas parental. Pretende também relacionar variáveis associadas às alterações da ansiedade e obter dados sobre a perceção do "ser clinicamente" empático. A sua colaboração contribuirá para o entendimento de vários aspetos, através da sua experiência enquanto progenitor/a, se aceitar participar neste estudo.

\section{Procedimentos:}

Este é um estudo científico que envolve uma entrevista, conversa informal e o preenchimento de questionários no local da consulta, antes e depois da mesma, onde lhe será pedido que fale, por palavras suas, acerca da sua experiência enquanto progenitor/a. A consulta de outro tipo de registos seus (páginas da web, processos clínicos, fotografias, etc.) pode também ajudar a complementar a informação.

\section{Riscos:}

A participação neste estudo não envolve riscos. Tudo o que acontece durante as entrevistas é estritamente confidencial. O único risco possível é sentir-se pouco à-vontade em abordar certos assuntos. Se isso acontecer, poderá comunicá-lo em qualquer altura da entrevista e o assunto será imediatamente mudado.

\section{Confidencialidade:}

Tudo o que acontece no contexto deste estudo é estritamente confidencial. Nomes e qualquer outra informação identificadora serão alterados e não serão disponibilizados a nenhum outro grupo, agência ou instituição.

\section{Direitos:}

A decisão de participar ou não neste estudo é inteiramente sua. Caso aceite participar, pode desistir a qualquer momento do estudo. Também pode recusar qualquer um dos procedimentos que lhe são propostos. A desistência deste estudo é confidencial e não tem qualquer implicação em termos de outros serviços que possa estar a receber de momento ou que possa vir a receber no futuro.

\section{Contactos:}

Qualquer questão relativa a este estudo pode ser dirigida aos seguintes números de telefone: (91) 1178966 (com Juliana Rocha) ou 225023963 do Serviço de Psicologia da Faculdade de Medicina da Universidade do Porto.

Aceito participar no estudo de investigação descrito acima e fico com uma cópia deste consentimento.

Participante: Data: 


\section{APPENDIX IV}

\section{QUESTIONÁRIO DE AUTO-AVALIACÃO}

Desenvolvido por Charles Spielberger

em colaboração com R.L. Gorush, R. Lushene, P. R. Vagg, e G. A. Jacobs

Traduzido por

Teresa McIntyre, M. A., e Lurdes Barros, LICSW

Copyright 1988

STAl Form Y-1

Data:

Idade:

Sexo: $\mathrm{M}$

Instruções: Abaixo encontra várias afirmações que as pessoas usam para descrever como se sentem. Leia cada frase cuidadosamente e depois ponha uma cruz no número à direita para indicar como se sente agora, isto é, neste momento. Não há respostas certas ou erradas. Não perca muito tempo em cada frase, dê a resposta que melhor parece descrever como se sente agora.

\begin{tabular}{|c|c|c|c|c|}
\hline & 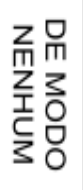 & $\begin{array}{l}\complement \\
3 \\
0 \\
0 \\
\complement \\
\bigcirc \\
0\end{array}$ & 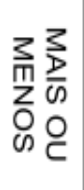 & $\begin{array}{l}3 \\
\text { 들 } \\
\text { O }\end{array}$ \\
\hline 1. Sinto-me calmo (a) & 1 & 2 & 3 & 4 \\
\hline 2. Sinto-me seguro (a) ou livre de perigo & 1 & 2 & 3 & 4 \\
\hline 3. Sinto-me tenso (a) & 1 & 2 & 3 & 4 \\
\hline 4. Sinto-me esgotado (a) & 1 & 2 & 3 & 4 \\
\hline 5. Sinto-me à vontade & 1 & 2 & 3 & 4 \\
\hline 6. Sinto-me transtornado (a) & 1 & 2 & 3 & 4 \\
\hline $\begin{array}{l}\text { 7. Presentemente estou preocupado (a) com coisas } \\
\text { más que possam acontecer }\end{array}$ & 1 & 2 & 3 & 4 \\
\hline 8. Sinto-me satisfeito (a) & 1 & 2 & 3 & 4 \\
\hline 9. Sinto-me assustado (a) & 1 & 2 & 3 & 4 \\
\hline 10. Sinto-me confortável & 1 & 2 & 3 & 4 \\
\hline 11. Sinto-me confiante em mim próprio (a) & 1 & 2 & 3 & 4 \\
\hline 12. Sinto-me nervoso (a) & 1 & 2 & 3 & 4 \\
\hline 13. Sinto-me agitado (a) & 1 & 2 & 3 & 4 \\
\hline 14. Estou indeciso (a) & 1 & 2 & 3 & 4 \\
\hline 15. Sinto-me repousado (a) & 1 & 2 & 3 & 4 \\
\hline 16. Sinto-me contente & 1 & 2 & 3 & 4 \\
\hline 17. Sinto-me preocupado (a) & 1 & 2 & 3 & 4 \\
\hline 18. Sinto-me confuso (a) & 1 & 2 & 3 & 4 \\
\hline 19. Sinto-me firme & 1 & 2 & 3 & 4 \\
\hline 20. Sinto-me bem & 1 & 2 & 3 & 4 \\
\hline
\end{tabular}

Obrigada pela sua participação neste questionário. 


\section{QUESTIONÁRIO DE AUTO-AVALIACÃO}

STAI Form Y-2

Data:

1

Instruções: Abaixo encontra várias afirmações que as pessoas usam para descrever como se sentem. Leia cada frase cuidadosamente e depois ponha uma cruz no número à direita para indicar como se sente geralmente, isto é, a maior parte do tempo. Não há respostas certas ou erradas. Não perca muito tempo em cada frase, dê a resposta que melhor parece descrever como se sente geralmente.

\begin{tabular}{|c|c|c|c|c|}
\hline & 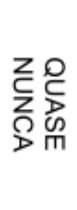 & 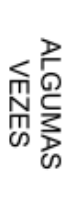 & 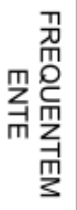 & 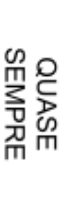 \\
\hline 21. Sinto-me bem & 1 & 2 & 3 & 4 \\
\hline 22. Sinto-me nervoso (a) e inquieto (a) & 1 & 2 & 3 & 4 \\
\hline 23. Estou satisfeito comigo próprio (a) & 1 & 2 & 3 & 4 \\
\hline $\begin{array}{l}\text { 24. Gostaria de ser tão feliz como os outros parecem } \\
\text { ser }\end{array}$ & 1 & 2 & 3 & 4 \\
\hline 25. Sinto que sou um fracasso & 1 & 2 & 3 & 4 \\
\hline 26. Sinto-me descansado (a) & 1 & 2 & 3 & 4 \\
\hline 27. Sinto-me calmo (a), refrescado (a) e composto (a) & 1 & 2 & 3 & 4 \\
\hline $\begin{array}{l}\text { 28. Sinto que as dificuldades se estão a acumular de } \\
\text { tal modo que não posso vencê-las }\end{array}$ & 1 & 2 & 3 & 4 \\
\hline $\begin{array}{l}\text { 29. Preocupo-me demasiado com coisas que } \\
\text { realmente não importam }\end{array}$ & 1 & 2 & 3 & 4 \\
\hline 30. Sou feliz & 1 & 2 & 3 & 4 \\
\hline 31. Tenho pensamentos incomodativos & 1 & 2 & 3 & 4 \\
\hline 32. Não tenho confiança em mim próprio (a) & 1 & 2 & 3 & 4 \\
\hline 33. Sinto-me seguro (a) ou livre de perigo & 1 & 2 & 3 & 4 \\
\hline 34. Faço decisões com facilidade & 1 & 2 & 3 & 4 \\
\hline 35. Sinto-me inadequado (a) & 1 & 2 & 3 & 4 \\
\hline 36. Sinto-me contente & 1 & 2 & 3 & 4 \\
\hline $\begin{array}{l}\text { 37. Vêm-me à cabeça pensamentos que não são } \\
\text { importantes e me incomodam }\end{array}$ & 1 & 2 & 3 & 4 \\
\hline $\begin{array}{l}\text { 38. Fico tão sentido (a) com desapontamentos que não } \\
\text { consigo deixar de pensar neles }\end{array}$ & 1 & 2 & 3 & 4 \\
\hline 39. Sou uma pessoa firme & 1 & 2 & 3 & 4 \\
\hline $\begin{array}{l}\text { 40. Fico tenso (a) ou transtornado (a) quando penso } \\
\text { nos meus interesses e preocupações mais } \\
\text { recentes }\end{array}$ & 1 & 2 & 3 & 4 \\
\hline
\end{tabular}

Obrigada pela sua participação neste questionário. 


\section{ANEXO V}

\section{CARE MEASURE}

Todos nós temos uma ideia de como correm as coisas. Pedimos-lhe que assinale as frases que se seguem relacionadas com a consulta que acabou de ter, colocando um $\mathrm{X}$ no quadro que melhor corresponda ao que sentiu para cada situação descrita na frase e segundo a seguinte escala: Fraco, Razoável (assimassim), Bom, Muito Bom, Excelente ou NÃO se Aplica à situação de consulta.

\begin{tabular}{|c|c|c|c|c|c|c|}
\hline Como esteve o profissional a... & Fraco & Razoável & Bom & $\begin{array}{c}\text { Muito } \\
\text { Bom }\end{array}$ & Excelente & $\begin{array}{l}\text { Não se } \\
\text { aplica à } \\
\text { situação de } \\
\text { consulta }\end{array}$ \\
\hline $\begin{array}{l}\text { 1. Fazê-lo sentir-se à vontade } \\
\text { (foi amigável e caloroso para consigo, tratando-o } \\
\text { com respeito, sem ser frio ou brusco) }\end{array}$ & & & & & & \\
\hline $\begin{array}{l}\text { 2. Deixá-lo contar a sua "história" } \\
\text { (deu-lhe tempo para poder livremente descrever a } \\
\text { sua doença por palavras suas, sem o interromper) }\end{array}$ & & & & & & \\
\hline $\begin{array}{l}\text { 3. A realmente Ouvi-lo } \\
\text { (prestou atenção ao que disse, sem olhar para } \\
\text { apontamentos ou computador, enquanto você estava } \\
\text { a falar) }\end{array}$ & & & & & & \\
\hline $\begin{array}{l}\text { 4. Estar interessado em si como pessoa } \\
\text { (perguntou sobre pormenores importantes da sua } \\
\text { vida, a sua situação atual, sem o tratando apenas } \\
\text { como um "número") }\end{array}$ & & & & & & \\
\hline $\begin{array}{l}\text { 5. Compreender realmente as suas } \\
\text { preocupações } \\
\text { (Comunicou-lhe que percebeu realmente as suas } \\
\text { preocupações, sem desprezar nenhum pormenor } \\
\text { importante) }\end{array}$ & & & & & & \\
\hline $\begin{array}{l}\text { 6. Mostrar afeto e compreensão } \\
\text { (Mostrou-se genuinamente preocupado, ligando-se a } \\
\text { si a um nível humano, não estando indiferente ou } \\
\text { desligado) }\end{array}$ & & & & & & \\
\hline $\begin{array}{l}\text { 7. Ser Positivo } \\
\text { (Teve abordagem e uma postura positivas, sendo } \\
\text { honesto/genuíno, mas não negativo sobre os seus } \\
\text { problemas) }\end{array}$ & & & & & & \\
\hline $\begin{array}{l}\text { 8. Explicar as coisas com clareza } \\
\text { (Respondeu completamente às suas perguntas, } \\
\text { explicando claramente, deu-lhe informação } \\
\text { adequada, não foi vago) }\end{array}$ & & & & & & \\
\hline $\begin{array}{l}\text { 9. Ajudá-lo a tomar o controlo } \\
\text { (Explorou consigo o que pode fazer para melhorar a } \\
\text { sua saúde, encorajou-o em vez de lhe dar sermões) }\end{array}$ & & & & & & \\
\hline $\begin{array}{l}\text { 10. Fazer um Plano de Ação Consigo } \\
\text { (Discutiu as opções, envolveu-o nas decisões, tanto } \\
\text { quanto você queria ser envolvido, sem ignorar os } \\
\text { seus pontos de vista) }\end{array}$ & & & & & & \\
\hline
\end{tabular}

